\title{
KEEFEKTIFAN BAHAN AJAR IPA BERBASIS PENDEKATAN SAVI UNTUK MENINGKATKAN KREATIVITAS PESERTA DIDIK SMPN 3 MATARAM
}

\section{THE EFFECTIVENESS OF SCIENCE INTRUCTIONAL MATERIALS BASED ON SAVI APPROACH TO ENHANCE CREATIVITY OF JUNIOR HIGH SCHOOL STUDENTS SMPN 3 MATARAM}

\author{
Fitran Sari' ${ }^{1)}$, Abdul Wahab Jufri ${ }^{2)}$, Sridana ${ }^{2)}$ \\ ${ }^{1)}$ Mahasiswa Program Magister Pendidikan IPA Universitas Mataram, Mataram \\ ${ }^{2)}$ Dosen Pendidikan Pascasarjana, Universitas Mataram, Mataram \\ Email: fitransari@yahoo.com
}

Diterima: 30 Agustus 2017. Disetujui 10 September 2017. Dipublikasikan: 30 September 2017

\begin{abstract}
Abstrak. Tujuan penelitian ini adalah untuk mengetahui keefektifan bahan ajar IPA berbasis pendekatan SAVI dalam meningkatkan kreativitas peserta didik SMP N 3 Mataram pada materi Sistem Organisasi Kehidupan. Populasi penelitian ini adalah seluruh peserta didik kelas VII berjumlah 172 orang. Sampel menggunakan peserta didik kelas VII-1 berjumlah 26 orang sebagai kelas eksperimen dan peserta didik kelas VII-3 berjumlah 26 orang sebagai kelas kontrol. Teknik pengambilan sampel menggunakan Probability Sampling yaitu Simple Random Sampling . Instrumen kreativitas terbukti valid $(>0,413)$ dan reliabel $(>0,80)$. Data kreativitas peserta didik dikumpulkan dengan tes essay. Rata-rata skor kreativitas peserta didik yang belajar menggunakan bahan ajar berbasis pendekatan SAVI adalah 61,48 sedangkan rata-rata skor peserta didik yang tidak menggunakan bahan ajar berbasis pendekatan SAVI adalah 30,31. Berdasarkan taraf signifikansi $\left(\mathrm{t}_{\text {hit }}=5,933>\mathrm{t}_{\text {tabel, }}=2,069, \mathrm{p}=0.000\right)$. Dengan demikian dapat disimpulkan bahwa bahan ajar SAVI efektif untuk meningkatkan kreativitas peserta didik.
\end{abstract}

Kata Kunci: bahan ajar. SAVI, kreativitas

\begin{abstract}
The study aimed to determine the effectiveness of science intructional materials based on SAVI approach (Somatic, Auditory, Visual, Intellectual) in improving the creativity of students of SMPN 3 Mataram on organizational life system topic. The population of this study was all seventh grade students consisting of 172 students. The samples of this research are class VII-1 (26 students) as experiment class and class VII-3 (26 students) as control class. Samples were taken using simple random sampling technique. Creativity instruments were proven to be valid $(>0.413)$ and reliable $(>0.80)$. Student creativity data was collected by essay test. The average creativity score of learners using learning materials based on SAVI and non-SAVI approach were 61.48 and 30.31, respectively. Based on the level of significance $\left(\mathrm{t}_{\text {calculated }}=5.933>\mathrm{t}_{\text {table }}=2.069, \mathrm{p}=0.000\right)$. It indicated that SAVI-based teaching materials are effective for improving the creativity of learners.
\end{abstract}

Keywords: teaching materials. SAVI, creativity

\section{PENDAHULUAN}

Undang-undang No 20 Tahun 2003 tentang Sistem Pendidikan Nasional pasal 1 angka 1 menyatakan bahwa pendidikan adalah usaha sadar dan terencana untuk mewujudkan suasana belajar dan proses pembelajaran agar peserta didik secara aktif mengembangkan potensi dirinya untuk memiliki kekuatan spritual, keagamaan, pengendalian diri, kepribadiaan, kecerdasan, akhlak mulia, serta keterampilan yang diperlukan dirinya, masyarakat, bangsa dan negara.

Proses pembelajaran pada satuan pendidikan sebaiknya diselenggarakan secara interaktif, inspiratif, menyenangkan, menantang, memotivasi peserta didik untuk berpartisipasi aktif serta memberikan ruang yang cukup bagi prakarsa, kreativitas, dan kemandirian sesuai dengan bakat, minat dan perkembangan fisik dan psikologis peserta didik. Terselenggaranya proses pembelajaran tersebut memerlukan pendidik yang kreatif dan inovatif, pendidik yang selalu melakukan perubahan dan pembaharuan dan mau mencoba sesuatu yang baru [1].

Perubahan paradigma pengajaran dan pembelajaran amat bergantung pada pemahaman para pendidik tentang dasar dan teori kependidikan yang dianut, tergantung cara 
pandang (point of vew) dan pola pikir (mindset) tentang peran dan kompetensi profesional pendidik dalam proses pembelajaran di sekolah (Budimansyah,2008). Pendidik yang profesional dapat melibatkan secara dominan peserta didik (student centered) dalam proses pembelajaran sehingga tidak lagi berpusat pada pendidik (teacher centered), peran pendidik adalah sebagai fasilitator.

Pendidik profesional perlu memahami karakteristik peserta didik salah satunya adalah gaya belajar untuk mencapai prestasi optimal. Peserta didik memiliki gaya belajar yang berbeda dan unik untuk menyerap pengetahuan. Adapun gaya belajar yang dimiliki peserta didik adalah gaya kinestetik, gaya belajar auditorial dan gaya belajar visual [2].

Perbedaaan individu dalam belajar seperti memahami gaya belajar peserta didik merupakan salah satu cara mengembangkan kreativitas peserta didik. Pendidik harus menghargai keunikan pribadi dan potensi setiap subyek didik dan tidak perlu selalu menuntut dilakukan hal-hal yang sama [3][4]. Keativitas subyek didik dapat ditingkatkan dengan cara menyediakan kesempatan di dalam kelas untuk berpikir divergen [3].

Gaya belajar yang berbeda dan unik yang dimiliki oleh peserta didik menjadi tolak ukur untuk merencanakan kegiatan pembelajaran yang baik. Perencanaan kegiatan pembelajaran yang baik perlu memperhatikan keterkaitan antara KI, KD, tujuan, indikator, bahan ajar, media, model, metode, pendekatan, sumber, alat evaluasi serta gaya belajar peserta didik. Adapun salah satu pendekatan yang memperhatikan perbedaan gaya belajar peserta didik adalah pendekatan SAVI (Somatic, Auditory, Visual, Intellectual) merupakan pendekatan belajar yang menggabungkan gerakan fisik dengan aktivitas intelektual dan penggunaan semua indera dapat memiliki efek mendalam pada pembelajaran [5].

$$
\text { Ilmu Pengetahuan Alam (IPA) }
$$

merupakan salah satu mata pelajaran kelompok ilmu pengetahuan dan teknologi yang sangat penting dalam rangka menghadapi era global, yang memungkinkan peserta didik memperoleh berbagai macam bekal positif yang memadai dan berguna dalam menghadapi tantangan tersebut. Bekal yang harus dimiliki antara lain: kemampuan berpikir kritis, logis, cermat, sistematis, kreatif dan inovatif. Pembelajaran konsep IPA harus mampu membelajarkan peserta didik untuk mengembangkan kemampuan berpikir kritis, logis, cermat, sistematis, kreatif, dan inovatif, sikap percaya diri, pantang menyerah, ulet, dan disiplin [6].
Berdasarkan latar belakang tersebut, maka melakukan penelitian untuk mengetahui keefektifan bahan ajar IPA berbasis pendekatan SAVI dalam upaya meningkatkan kreativitas peserta didik.

\section{METODE PENELITIAN}

\section{Jenis dan Desain Penelitian}

Penelitian ini termasuk penelitian kuasi eksperimen yaitu penelitian menguji keefektivan bahan ajar IPA berbasis pendekatan SAVI. Desain penelitian menggunakan Posstes Only Non Equivalen Control Group Desaign, yaitu penelitian yang dilakukan pada dua kelompok kelas yaitu kelas eksperimen dan kelas kontrol dengan melakukan posttest setelah belajar menggunakan bahan ajar berbasis pendekatan SAVI.

\section{Tempat dan waktu penelitian}

Penelitian dilaksanakan di SMP Negeri 3 Mataram pada semester genap tahun 2016/2017.

\section{Populasi dan sampel}

Populasi dalam penelitian ini adalah seluruh kelas VII SMP N 3 Mataram tahun pelajaran 2016/2017 berjumlah 172 orang. Sedangkan sampel yang digunakan 2 kelas yaitu kelas VII-1 sebagai kelas eksperimen menggunakan bahan ajar berbasis pendekatan SAVI berjumlah 26 orang dan kelas VII-3 sebagai kelas kontrol tidak menggunakan bahan ajar berbasis pendekatan SAVI berjumlah 26 orang. Teknik pengambilan sampel mengggunakan Probability Sampling yaitu Simple Random Sampling.

Instrumen penelitian dan Teknik
pengumpulan data
Instrumen yang digunakan dalam penelitian ini adalah tes kreativitas yang dilakukan kepada peserta didik kelas eksperimen setelah menggunakan bahan ajar berbasis pendekatan SAVI. Serta peserta didik kelas kontrol menggunakan bahan ajar konvensional materi. Sistem Organisasi Kehidupan. Tes kreativitas berupa tes tertulis dalam bentuk uraian (essay) terdiri dari 7 butir soal mencakup aspek fluency (kelancaran), flexibility (keluwesan), Novelty (kebaharuan) [7].

Teknik analisa data yang digunakan adalah analisis kuantitatif. yang digunakan dengan menjumlahkan skor setiap aspek kreativitas. Tes yang digunakan sudah diuji validitas dan reliabilitas menggunakan Anates. 
Sedangkan untuk menguji efektivitas bahan ajar upaya meningkatkan kreativitas dianalisis secara statistis t-tes (Independen Sample test) menggunakan SPSS.

\section{HASIL DAN PEMBAHASAN}

Tes kreativitas diberikan kepada peserta didik setelah menggunakan pendekatan SAVI dalam kegiatan pembelajaran. Sebelum tes kreativitas digunakan maka dilakukan uji validitas dan reliabilitas menggunakan Anates dan semua butir tes valid > 0,413 dan reliabel $(0,94)$. Hasil uji validitas dan reliabilitas disajikan pada Tabel 1 .

Uji efektivitas bahan ajar berbasis pendekatan SAVI terhadap peserta didik kelas eksperimen dan peserta didik kelas kontrol memperoleh hasil, rata-rata skor pada aspek Fluency kelas eksperimen 62 kelas kontrol 31, aspek Fleksibility kelas ekperimen 79 kelas kontrol 49, aspek Novelty kelas eksperimen 46 dan kelas kontrol 19. Data rata-rata skor aspek kreativitas kelas eksperimen dengan kelas kontrol disajikan pada Gambar 1. Rata-rata skor peserta didik kelas eksperimen lebih tinggi dibandingkan dengan rata-rata skor kelas kelas kontrol disajikan pada Gambar 2.

Uji efektivitas bahan ajar tingkat signifikanya diuji secara statistic dengan t-test (Independent Sample Tes) menggunakan SPSS. Data posttest kreativitas peserta didik disajikan pada Tabel 2.

Tabel. 1 Data Hasil Validitas dan Reliabilitas Tes Kreativitas

\begin{tabular}{cccc}
\hline No & $\begin{array}{c}\text { Validitas } \\
\text { (Pearson correlation) }\end{array}$ & Keterangan & $\begin{array}{l}\text { Reliabilitas } \\
\text { (Cronbach's alpha) }\end{array}$ \\
\hline 1 & 0,602 & Valid & \\
2 & 0,725 & Valid & 0,94 \\
3 & 0,742 & Valid & \\
4 & 0,875 & Valid & \\
5 & 0,629 & Valid & \\
6 & 0,623 & Valid & \\
7 & 0,786 & Valid & \\
\hline
\end{tabular}

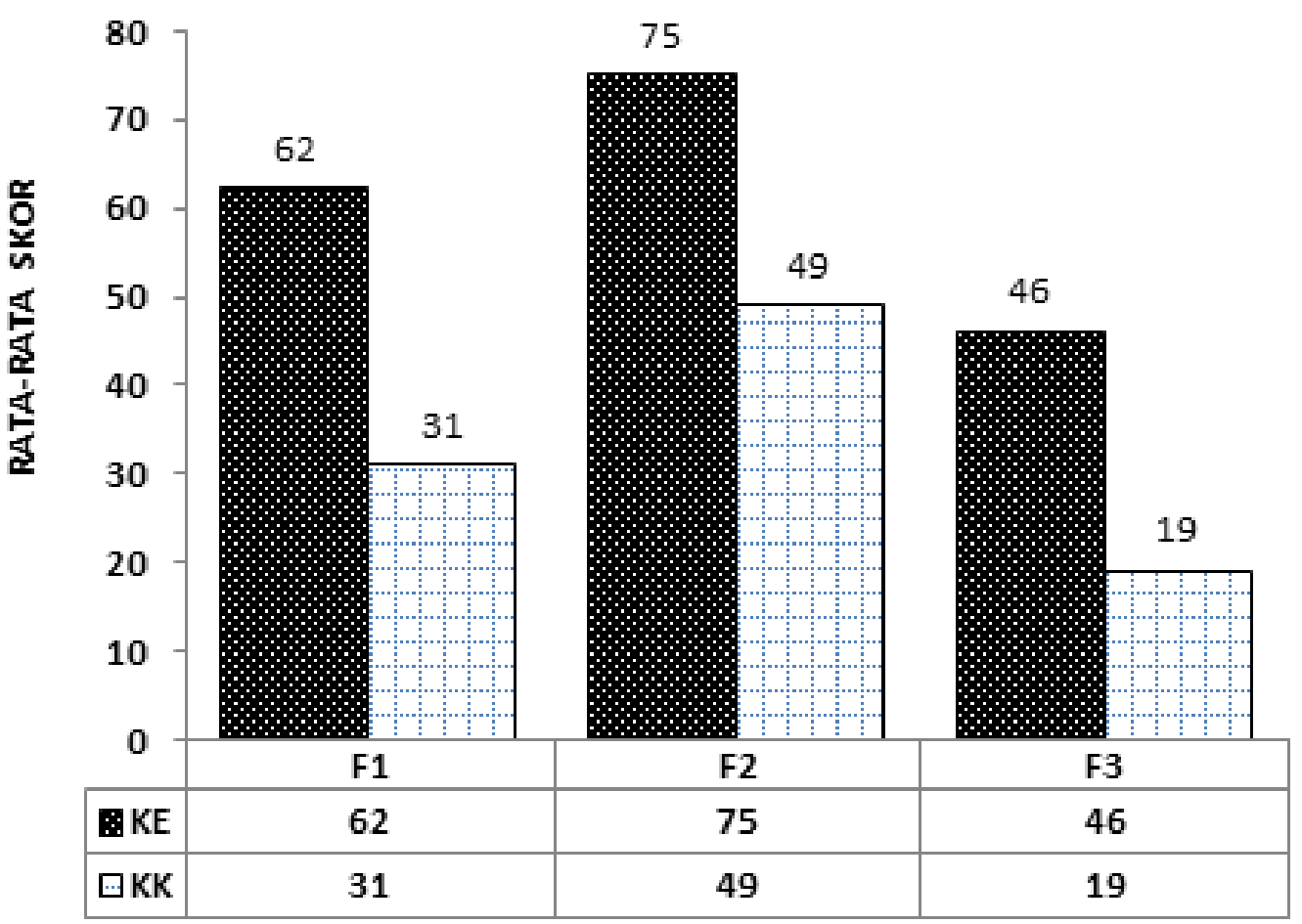

Gambar1. Perbandingan rata-rata skor kreativitas berdasarkan aspek. $(\mathrm{F} 1=$ Fluency, $\mathrm{F} 2=$ Flexibility, $\mathrm{F} 3=$ Novelty $\mathrm{KE}=$ kelas eksperimen $\mathrm{KK}=$ kelas kontrol) 


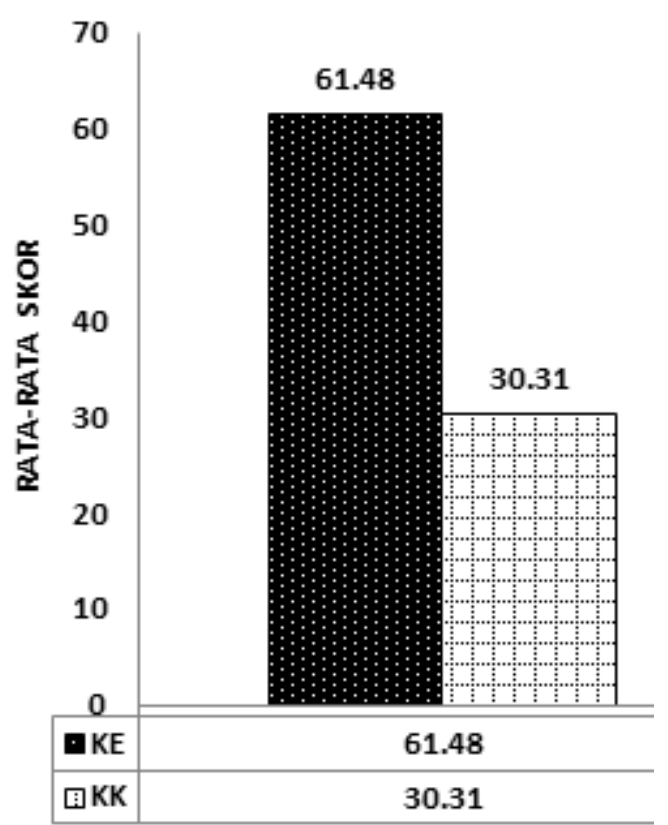

Gambar.2 Rata-rata skor kreativitas kelas eksperimen dengan kelas control. (F1= Fluency, F2= Flexibility, F3 = Novelty $\mathrm{KE}=$ kelas eksperimen $\mathrm{KK}=$ kelas kontrol)

Tabel.2 Data posttes kreativitas

\begin{tabular}{ccccc}
\hline Data & $\mathrm{t}_{\text {hitung }}$ & $\mathrm{t}_{\text {tabel }}$ & Sig (2-tailled) & Signifikan \\
\hline Kreativitas & 3,933 & 2,069 & 0.000 & 0,05 \\
\hline
\end{tabular}

Berdasarkan data pada Tabel 2 hasil posttes menunjukkan $t_{\text {hitung }}>t_{\text {tabel }} \quad \mathrm{p}=0.000$ dengan taraf signifikan 0,05 .

Tes kreativitas yang digunakan diuji validitas dan reliabilitas. Berdasarkan uji validitas butir soal maka dari keseluruhan butir soal memiliki $r_{\text {hitung }}>r_{\text {tabel }}(0,413)$ dengan taraf signifikan 0,05. Sedangkan berdasarkan uji reliabilitas pada butir soal kreativitas maka memperoleh reliabilitas sangat tinggi karena koefisiesn korelasinya lebih besar dari 0.80 . Suatu instrumen dikatakan valid apabila mampu mengukur apa yang diinginkan, suatu instrument yang valid atau sahih mempunyai validitas tinggi dan sebaliknya. Sedangkan Realiabel apabila instrumen cukup dapat dipercaya untuk digunakan sebagai alat pengumpul data karena instrumen. tersebut sudah baik [8].

Kreativitas peserta didik perlu dilatih dalam kegiatan pembelajaran. Hal ini ditujukkan rata-rata skor setiap aspek kreativitas pada kelas eksperimen lebih tinggi dibandingkan dengan kelas kontrol. Kreativitas peserta didik tidak datang dengan sendirinya tapi dipengaruhi oleh faktor internal dan eksternal [3]. Jika kebutuhan anak yang berbakat dipertimbangkan, dan dirancang program untuk memenuhi kebutuhan pendidikan mereka sejak awal, maka mereka mununjukkan peningkatan yang nyata dalam prestasi, sehingga tumbuh rasa kompetensi dan rasa harga diri [9]. Dari keseluruhan Aspek kreativitas yang dikembangkan pada penelitian ini, aspek Fleksibility memiliki rata-rata skor yang lebih tinggi dibandingkan rata-rata skor Fluency dan Novelty. Rata-rata skor peserta didik yang menggunakan bahan ajar berbasis pendekatan SAVI lebih tinggi dari peserta didik yang tidak menggunakan bahan ajar berbasis pendekatan SAVI, namun merujuk pada ketuntasan minimal yang ditentukan oleh BNSP yaitu 75, maka sebanyak 8 orang atau $35 \%$ dinyatakan tuntas pada kelas eksperimen. Sedangkan pada kelas kontrol tidak ada peserta didik mencapai nilai ketuntasan minimal.

Uji efektivitas $\mathrm{t}$ hitung=5,933 $>\mathrm{t}$ tabel $=$ 2.069 dan tingkat signifikan $p=0.000<p=$ 0,05 , sehingga bahan ajar berbasis pendekatan SAVI efektif untuk meningkat kreativitas peserta didik sehingga dapat digunakan dalam kegiatan pembelajaran. Penggunaan pendekatan SAVI dalam kegiatan pembelajaran dapat meningkatkan kreativitas peserta didik [10]. 


\section{KESIMPULAN}

Berdasarkan uji efektivitas menunjukkan bahan ajar berbasis pendekatan SAVI mampu meningkatkan kreativitas peserta didik materi Sistem Organisasi Kehidupan kelas VII SMPN Negeri 3 Mataram

\section{SARAN}

Berdasarkan hasil penelitian, dapat dikemukakan saran - saran sebagai berikut :

1) Untuk melatih kreativitas peserta didik hendaknya menggunakan bahan ajar yang melibatkan semua alat indera dan Intelektual.

2) Mengigat pentingnya kreativitas peserta didik maka pendidik dalam kegiatan pembelajaran hendaknya menyediakan media, alat dan bahan serta RPP sebagai pendukung untuk meningkatkan kreativitas peserta didik.

3) Pendidik disarankan untuk menggunakan bahan ajar berbasis pendekatan SAVI dalam kegiatan pembelajaran.

\section{DAFTAR PUSTAKA}

[1] Budimanyah, D., Suparlan. 2008. PAIKEM Pembelajaran aktif, Efektif dan Menyenangkan. Bandung: PT. Genesindo.

[2] Ramadhy.S., Permadi, D., 2009. Bagimanakah mengembangkan kecerdasan?. Bandung: PT Sarana Panca Karya Nusa.

[3] Furkan, N., Yasin, I. 2014. PercikPercik Pemikiran Pendidikan, Teori, Praktik, Kebijakan. Yokyakarta: Magnum Pustaka Utama.

[4] Munandar, U. 1995. Pengembangan Kreativitas Anak Berbakat. Jakarta: Rineka Cipta.

[5] Meier, Dave. 2000. The Accelerated Learning Handbook: A creative Guide to Designing and Delivering Faster, More Effective Training Programs. New York : The McGraw-Hill Companies, Inc.

[6] Lestari, I. 2010. Pengembangan bahan ajar perkembangan anak usia SD dan filsafat pendidikan sebagai sarana belajar mandiri mahasiswa, Desertasi S3. Universitas Negeri Jakarta.

[7] Marwiyah, S., Kamid, Risnita. 2015. Pengembangan Instrumen Penilaian Keterampilan Berpikir Kreatif pada Mata Pelajaran IPA Terpadu Materi Atom, Ion, dan Molekul SMP Islam Al Falah (Development of Instrument Assessment of Creative Thinking Integrated Science in Studying Atom, Ion, and Molecule Material on $\mathrm{Al}$ Falah Islamic Junior High School. Edu-Sains Vol. 4 No. 1, Januari 2015.

[8] Arikunto, S. 2014. Prosedur Penelitian Suatu Pendekatan Praktik.Jakarta:Rineka Cipta.

[9] Sukmadinata, N.S. 1997. Pengembangan kurikulum teori dan praktik. Bandung: PT Remaja Rosdakarya.

[10]Sapti, M., dan Suparwati. 2011. An Experiment Of Mathematics Teaching Using SAVI Approach And Conventional Approach Viewed From The Motivation Of The Students Of Sultan Agung Junior High School In Purworejo. This paper has been presented at International Seminar and the Fourth National Conference on Mathematics Education 2011 "Building the Nation Character through Humanistic Mathematics Education". Department of Mathematics Education, Yogyakarta State University, Yogyakarta, July 2123201. 